\title{
The Duty of Good Faith in American Corporate Law
}

by

\author{
Melvin A. Eisenberg*
}

An important development in American corporate law is the recent explicit recognition, in a series of Delaware cases, that corporate managers owe a fiduciary duty of good faith in addition to their traditional duties of care and loyality. The duty of good faith was not created by those cases. On the contrary, the duty bas long been explicit under the statutes and bas also long existed implicitly in the case law. Nevertheless, the explicit recognition of the duty of good faith in recent Delaware cases shines a spotlight on that duty, and therefore makes it especially important to develop the contours of the duty and to examine the duty from a normative perspective.

Briefly, the duty of good faith in American corporate law is comprised of a general baseline conception and specific obligations that instantiate that conception. The baseline conception consists of four elements: subjective bonesty, or sincerity; nonviolation of generally accepted standards of decency applicable to the conduct of business; nonviolation of generally accepted basic corporate norms; and fidelity to office. Among the specific obligations that instantiate the baseline conception are the obligation not to knowingly cause the corporation to disobey the law and the obligation of candor even in non-self-interested contexts.

Turning to the normative issue, there are several basic reasons why the duty of good faith is desirable. To begin with, the duties of care and loyalty do not

* Koret Professor of Law, School of Law, University of California, Berkeley (Boalt Hall); Stephen and Barbara Friedman Visiting Professor of Law, Columbia Law School. A.B. 1956, Columbia University; LL.B. 1959, Harvard University. Earlier versions of this Article were presented on the occasion of the award of an honorary Doctor of Laws degree to the author by the University of Cologne in 2004, and later as the Pileggi Lecture in Wilmington, Delaware in 2004. A longer version of this Article will appear shortly in the Delaware Journal of Corporate Law. I thank Jesse Fried, Jim Hanks, Jack Jacobs, Amir Licht, Mary Siegel, Marshall Small, and Leo Strine for their very important comments on earlier drafts, and Shawn Bayern and Joel Willard for their valuable research assistance. For ease of exposition, all references in this paper statutory or case law, or to general legal principles, are to be understood as referring exclusively to American law, even when not explicitly so stated. 
cover all types of improper conduct by managers, because certain kinds of improper managerial conduct fall outside the spheres of those duties. Most of these types of conduct fall within the duty of good faith. Furthermore, various rules limit a manager's accountability under the duties of care and loyalty, and these limiting rules should be and are inapplicable to conduct that violates the duty of good faith. Moreover, the duties of care and loyalty characteristically (although not invariably) function as platforms for liability rules, while the duty of good faith characteristically (although not invariably) functions as a condition to the application of rules that do not in themselves impose liability. This difference in characteristic function makes it desirable to treat good faith separately from care and loyalty. Finally, the duty of good faith provides a principled basis for the courts to develop new specific fiduciary obligations that come to be seen as appropriate in response to changes in social and business norms, and in the general understanding of efficiency and other policy considerations that are applicable to corporate law, but cannot be easily accommodated within the duties of care or loyalty.

\section{Table of Contents}

ECFR 2006, 1-44

I. Introduction $\ldots \ldots \ldots \ldots \ldots \ldots \ldots \ldots \ldots \ldots \ldots$

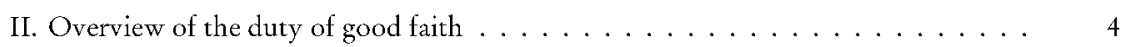

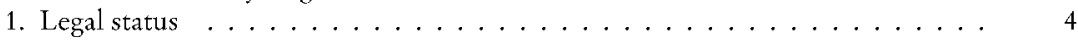

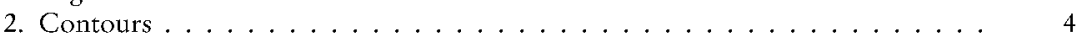

3. Normative Considerations ..................... 4

III. An Introduction to the legal status of the duty of good faith under the statutes and

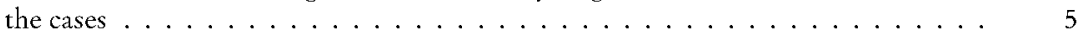

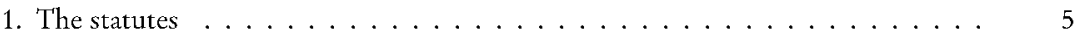

2. The cases ........................ 7

IV. The baseline conception of the duty of good faith . . . . . . . . . . 9

V. Normative considerations . . . . . . . . . . . . . . . . . . . . 14

1. The duty of good faith covers managerial conduct that is improper but does not fall within the duties of care or loyalty $\ldots \ldots \ldots \ldots \ldots$

2. Certain rules that limit the duties of care and loyalty should not and do not apply to conduct that lacks good faith . . . . . . . . . . . . . .

3. The duty of good faith characteristically functions differently than the duties of care and loyalty . . . . . . . . . . . . . . . .

4. The duty of good faith provides the courts with a principled basis for developing new specific fiduciary obligations in response to social changes . . . . . 17

VI. Some specific obligations under the duty of good faith . . . . . . . . . . . . 18

1. The obligation not to knowingly cause the corporation to violate the law ... 18

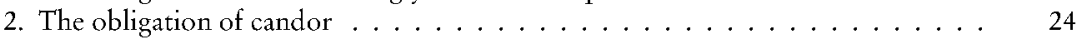

3. Impermissible motives . . . . . . . . . . . . . . . . . . . 34

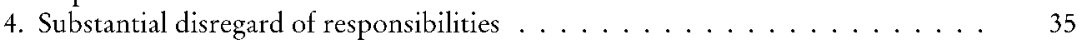

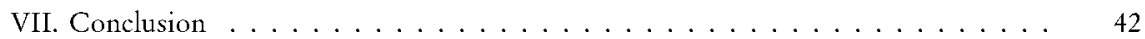




\section{Introduction}

An important development in American corporate law is the recent explicit recognition in a series of Delaware cases that corporate managers - directors and officers - owe a duty of good faith in addition to their duties of care and loyalty. ${ }^{1}$ Because this development has been attended by a certain degree of controversy, three issues require examination: (1) Does corporate law impose a fiduciary duty of good faith? (2) If so, what should be and are the contours of that duty? (3) Is an independent duty of good faith justified on normative grounds?

These three issues are tightly connected. For example, the legal status of the duty of good faith depends in part on whether the duty is normatively justified, and whether the duty is normatively justified depends in part upon the contours of the duty. Therefore, it is difficult to resolve any one of these three issues in isolation. This Article deals with the problem of interconnectedness as follows. Part II consists of an overview of the legal status of the duty of good faith in American corporate law, the contours of that duty, and the normative justifications of that duty. Part III develops the legal status of the duty in greater depth. Part IV develops the contours of the duty in greater depth, by setting out the general baseline conception of the duty. Part V develops the normative justifications of the duty in greater depth. Finally, Part VI considers some of the specific obligations that instantiate the general baseline conception of the duty of good faith, and some important recent cases concerning that duty.

1 The emerging recognition of the duty of good faith in Delaware case law was first fully developed and illuminated by Hillary Sale in her leading article, "Delaware's Good Faith", 89 Cornell L. Rev. 456 (2004). Shortly thereafter, a number of other significant articles on that issue appeared. See, e.g., Matthew R. Berry, "Does Delaware's Section 102(b)(7) Protect Reckless Directors From Personal Liability? Only if Delaware Courts Act in Good Faith", 79 Wash. L. Rev. 1125 (2004); John L. Reed \& Matt Neiderman, "Good Faith and the Ability of Directors to Assert $\$ 102(b)(7)$ of the Delaware Corporation Law as a Defense to Claims Alleging Abdication, Lack of Oversight, and Similar Breaches of Fiduciary Duty", 29 Del. J. Corp. Law 111 (2004); David Rosenberg, "Making Sense of Good Faith in Delaware Corporate Fiduciary Law: A Contractarian Approach", 29 Del. J. Corp. Law 491 (2004). For an early, more targeted, discussion, see Deborah DeMott, "Puzzles and Parables: Defining Good Faith in the MBO Context", 25 Wake Forest L. Rev. 15 (1990). All of these articles also discuss, to varying extents, the parameters of the duty of good faith. See, e.g., Sale, supra, at 482-94. The present Article primarily concerns that issue in American corporate law generally, and only secondarily concerns Delaware law specifically. As to American fiduciary duties as legal transplants into Continental corporate laws see Holger Fleischer, "Legal Transplants in European Company Law - The Case of Fiduciary Duties”, II/3 ECFR 378 (2005). 


\section{Overview of the duty of good faith}

Here is a summary of the legal status, contours, and desirability of the duty of good faith.

\section{Legal status}

Although the duty of good faith has only recently been explicitly recognized in the case law, that duty has long been established by the statutes. Many or most American corporate statutes explicitly impose the duty of good faith on directors, officers, or both. In addition, in all or virtually all statutes the duty of good faith is implicitly imposed under a variety of provisions, such as those concerning indemnification. The duty of good faith also has long been implicitly recognized in the case law - for example, as an element of the business judgment rule. Finally, within the last fifteen years, the duty has been explicitly recognized in a number of Delaware cases.

\section{Contours}

The duty of good faith in corporate law is comprised of a general baseline conception, and specific obligations that instantiate that conception. The baseline conception consists of four elements: subjective honesty, or sincerity; nonviolation of generally accepted standards of decency applicable to the conduct of business; nonviolation of generally accepted basic corporate norms; and fidelity to office. Among the specific obligations that instantiate the baseline conception are the obligation not to knowingly cause the corporation to disobey the law, and the obligation of candor even in non-selfinterested contexts.

\section{Normative Considerations}

The duty of good faith is supported by four normative considerations:

First, the traditional duties of care and loyalty do not cover all types of improper managerial conduct. The standard of conduct under the duty of care essentially requires a manager, when not acting in his own self-interest, to perform his duties in a manner that he reasonably believes to be in the best interests of the corporation, with a view maximizing corporate profit and shareholder gain. The standard of conduct under the duty of loyalty essentially requires a manager to act fairly when he acts in his own pecuniary self-interest or the pecuniary interest of an associate or a closely related family member. Certain important kinds of improper managerial conduct fall outside the spheres of those duties. Most of these types of conduct fall within the duty of good faith. 
Second, various rules limit a manager's accountability under the duties of care and loyalty. These include the business-judgment rule; rules that make harm or unfairness to the corporation, or profit to the manager, elements of a breach of those duties; and rules allowing "disinterested" directors who are friends and colleagues of a self-interested director to insulate that director from liability for self interested transactions. These accountability-limiting rules should be and are inapplicable to conduct that violates the duty of good faith.

Third, the duties of care and loyalty characteristically (although not invariably) function as platforms for liability rules. In contrast, the duty of good faith characteristically (although not invariably) functions as a condition to the application of rules that do not in themselves impose liability, such as rules concerning indemnification. This difference in characteristic function makes it desirable to treat good faith separately from care and loyalty.

Fourth, the duty of good faith provides the courts with a principled basis for developing new specific fiduciary obligations that come to be seen as appropriate in response to changes in social and business norms, and in the general understanding of efficiency and other policy considerations that are applicable to corporate law, but cannot be accommodated within the duties of care or loyalty.

\section{An introduction to the legal status of the duty of good faith under the statutes and the cases}

\section{The statutes}

There is little doubt that as a matter of positive law, corporate managers owe a duty of good faith. To begin with, that duty is explicitly imposed on directors, officers, or both, under many or most statutes. For example, section 8.30 of the Model Business Corporation Act, which has been adopted in many states, provides that "Each member of the board of directors, when discharging the duties of a director, shall act $\ldots$ in good faith. ... "2 A counterpart provision, section 8.42 , provides that "An officer, when performing in such capacity, shall act ... in good faith ... ." Similarly, the New York statute, and many others, provide that " $A$ director shall perform his duties as a director ... in good faith ...." ${ }^{4}$

In addition, in all or virtually all states, various statutory provisions make the applicability of important rules conditional on managerial good faith. For ex-

2 Model Business Corporation Act $\$ 8.30(a)$.

$3 I d . \$ 8.42$.

4 N.Y. Bus. Corp. Law $\$ 717(a)$. 
ample, sections 145(a) and (b) of the Delaware General Corporation Law explicitly provide that under designated conditions a corporation has the power to indemnify a manager for the costs and outcomes of litigation and other proceedings, provided the manager acted in good faith. ${ }^{5}$ The strength of the good faith requirement in this context is brought out by cases that consider a manager's right to indemnification under private arrangements that are adopted pursuant to statutory provisions that do not explicitly require good faith as a condition to indemnification. For example, section $145(\mathrm{f})$ of the Delaware statute provides that: "The indemnification ... provided by, or granted pursuant to ... this section shall not be deemed exclusive of any other rights to which those seeking indemnification ... may be entitled under any by-law, agreement, vote of stockholders or disinterested directors or otherwise ... ." In Waltuch v. Conticommodity Services, Inc., Article Ninth of the certificate of incorporation of Conti, a Delaware corporation, gave managers a right to indemnification under defined circumstances, and did not require a showing of good faith. Waltuch brought suit against Conti under Article Ninth for indemnification of unreimbursed expenses that he had incurred in certain proceedings. Conti responded that Waltuch's claim was barred because he did not establish that he had acted in good faith. Waltuch countered that Article Ninth was authorized by section $145(f)$, and nothing in 145 (f) required good faith. The Second Circuit held that notwithstanding the absence of an explicit requirement of good faith in section 145(f), Waltuch could not recover unless he established that he had acted in good faith. Other cases have taken the same position, typically by subscribing to Waltuch. ${ }^{8}$

5 Del. Gen. Corp. Law $\$ 145(a)$, (b).

6 Id. $\$ 145(\mathrm{f})$.

788 F.3d 87 (2d Cir. 1996).

8 See Kappor v. Fujisawa Pharmacentical Co., 1197 Del. Super. LEXIS 386 at $* 11-12$ (1997) ("I find persuasive the analysis in Waltuch v. Conticommodity Services, Inc., 88 F.3d 87 (1996) wherein the court held that subsection (f) 'does not speak in terms of corporate power, and therefore cannot be read to free a corporation from the ... limitations explicitly imposed in subsections (a) and (b)' "); Von Feldt v. Stifel Financial Corp., 1999 WL $413393 * 2$ ("While $\$ 145(\mathrm{f})$ permits indemnification on terms other than as set forth in the rest of $\mathbb{1 4 5}$, such other indemnification must be consistent with the policies expressed in the other parts of $\$ 145$. Thus, in Waltuch v. Conticommidity Services, Inc., a provision in the company's articles of incorporation provided for mandatory indemnification unqualified by a requirement (as set forth in $\$ 145(a)$ ) that the person seeking indemnification show that he acted in good faith. The Second Circuit had little difficulty in finding, first, that any provision for additional indemnification must be consistent with the provisions of $\$ 145$ and, second, that good faith was necessary for such consistency ... . It should now be clear that, as far as $\$ 145$ is concerned, Delaware corporations lack the power to indemnify a party who did not act in good faith or in the best interests of the corporation"); Owens Corning v. National Union Fire Ins. Co., 257 F.3d 
In parallel with the indemnification statutes, statutes that insulate directors against liability for self-interested transactions that are approved by disinterested directors are applicable only if the disinterested directors act in good faith. Satisfaction of the duty of good faith is also a condition to the applicability of many of the recently adopted exculpation or liability-shield statutes. For example, the Delaware statute permits a certificate of incorporation to include:

A provision eliminating or limiting the personal liability of a director to the corporation or its stockholders for monetary damages for breach of fiduciary duty as a director, provided that such provision shall not eliminate or limit the liability of a director: (i) for any breach of the director's duty of loyalty to the corporation or its stockholders; (ii) for acts or omissions not in good faith or which involve intentional misconduct or a knowing violation of law; ... or (iv) for any transaction from which the director derived an improper personal benefit...?

\section{The cases}

In addition to the explicit and implicit legislative imposition of the duty of good faith under the statutes, that duty has long been implicit in the case law. For example, it is well established that if a manager is sued for violation of the duty of care, the manager can invoke the protective business judgment rule if, but only if, he acted in good faith. This requirement is reflected in the formulation of the business judgment rule in the American Law Institute's Principles of Corporate Governance:

484, 494 ( $6^{\text {th }}$ Cir. 2001) ("The requirement of good faith on the part of the directors indemnified under $\$ \$ 145$ (a), (b) ... cannot be waived by attempting to extend indemnification even further... . Owens Corning cannot avoid the good-faith requirement through provision of an alternative basis for indemnification; ... [T] he Delaware chancery courts have generally required good faith to be present for permissive indemnification, an interpretation also followed by the well-reasoned opinion of the Second Circuit in Waltuch"); Mayer v. Executive Telecard, Ltd., 705 A.2d 220, 225 n. 6 (Del. Ch. 1997) (" $[$ t] his Court agrees with the Second Circuit's construction of $\$ 145$ that a Delaware corporation lacks the power to indemnify a party who did not act in good faith") (citing Waltuch). Cf. In re Landmark Land Co. 76 F.3d 553 (1996) (requirement of good faith under the California and other indemnification statutes); Plate v. Sun-Diamond Growers, 225 Cal. App. 3d 1115, 275 Cal. Rptr. 667 (1970) (requirement of good faith under the California statute).

9 Del. Gen. Corp. Law $\$ 102(b)(7)$ (emphasis added). 
A director or officer who makes a business judgment in good faith fulfills the duty [of care] ... if the director or officer:

(1) is not interested ... in the subject of the business judgment;

(2) is informed with respect to the subject of the business judgment to the extent the director or officer reasonably believes to be appropriate under the circumstances; and

(3) rationally believes that the business judgment is in the best interests of the corporation. ${ }^{10}$

Similarly, it is well established that corporate managers have an obligation not to knowingly cause the corporation to violate the law. This obligation has traditionally been conceived as stemming from the duty of good faith, and as I will show in Part VI, cannot be rationalized under either the duty of care or the duty of loyalty. ${ }^{11}$

In short, the duty of good faith has long been both explicit and implicit in the corporation statutes and implicit in the case law. Recently, it has become explicit in the case law as well. As early as 1993, the Delaware Supreme Court stated, in Cede II, that a "plaintiff assumes the burden of providing evidence that directors, in reaching their challenged decision, breached any one of the triads [sic] of their fiduciary duty - good faith, loyalty or due care."12 (Emphasis by the court.) This triadic formulation was repeated three years later in Cede III,${ }^{13}$ where the Court stated that "to rebut the presumption [of the business-judgment rule], a shareholder plaintiff assumes the burden of providing evidence that the board of directors, in reaching its challenged decision, breached any one of its triad of fiduciary duties: good faith, loyalty, or due care." 14 In 1999, the Court stated in Malone v. Brincat ${ }^{15}$ that "this court has endeavored to provide the directors with clear beacons and brightly lined-channel markers as they navigate with due care, good faith, and loyalty on behalf of a Delaware corporation and its shareholders." In 2001, the Court stated in Emerald Partners v. Berlin" that "The directors of Delaware corporations have a triad of primary fiduciary duties: due care, loyalty, and good faith. ... [T] he shareholders of a Delaware corporation are entitled to rely upon their board of directors to discharge each of their three primary fidu-

10 ALI, Principles of Corporate Governance $\$ 4.01$ (c) (emphasis added).

11 See V 1., infra.

12 Cede E Co. v. Technicolor, 634 A.2d 345, 361 (Del. Supr. 1993) (emphasis in original).

13 Cinerama, Inc. v. Technicolor, Inc., 663 A.2d 1156 (Del. Supr. 1995).

14 Id. at 1163.

15722 A.2d 5, 9 (Del. Supr. 1999).

16787 A.2d 85 (Del. Supr. 2001). 
ciary duties at all times." ${ }^{17}$ The court continued, "[u]nless there is a violation of the duty of loyalty or the duty of good faith, a trial on the issue of entire fairness is unnecessary because a Section 102(b)(7) provision will exculpate director defendants from paying monetary damages that are exclusively atributable to a violation of the duty of care." ${ }^{\prime 18}$ One commentator counted more than a dozen Delaware cases decided by mid-2002 that adopted the triadic formulation of the duties of corporate managers, ${ }^{19}$ and this duty has been further recognized by other Delaware and non-Delaware cases decided since that time, some of which will be considered in Part VI. ${ }^{20}$

\section{The baseline conception of the duty of good faith}

In 1968, Robert Summers published an influential article arguing that in contract law, good faith was best understood as an excluder - that is, "a phrase which has no general meaning ... of its own, but which ... serves to exclude many heterogeneous forms of bad faith." "21 "In cases of doubt," Summers suggested, "a lawyer will determine more accurately what the judge means by ... 'good faith' if [the lawyer] does not ask what good faith itself means, but rather asks: What ... does the judge intend to rule out by his use of this phrase?" 22

Certainly, Summers made an important point. ${ }^{23}$ It is easier to characterize a given action as lacking good faith than to provide a general definition of good faith. ${ }^{24}$ Nevertheless, as Deborah DeMott has observed, "[in a] contractual

\section{$17 I d$. at 90 .}

18 Id. at 92 (emphasis added). See also McMullin v. Beran, 765 A.2d 910, 918 (Del. 2000), "The Chemical Board owe[s] fiduciary duties of care, loyalty and good faith to all Chemical shareholders in recommending a sale of the entire corporation."

19 Charles Hansen, "Sowing the Seeds of Confusion: The Ephemeral Triad", 73 Aspen Law \& Business Corporations, No. 11, 1,2 (June 3, 2002).

20 See VI, infra. For a comprehensive history of the development of the doctrine of good faith in explicit terms under Delaware case law, see Sale, supra note 1.

21 R.S. Summers, "Good Faith' in General Contract Law and the Sales Provisions of the Uniform Commercial Code", 54 Va. L. Rev. 195, 196 (1968) (emphasis added).

$22 \mathrm{Id}$. at 200 (emphasis in original).

23 In fact, Summers's analysis made its way into the commentary to the good-faith provision in the Restatement (Second) of Contracts. Restatement Second of Contracts $\$ 205$, Comment d.

24 Accordingly for ease of exposition, unless the context indicates otherwise, in the balance of this Article I will use the terms action and conduct interchangeably, and I will use the term lacks good faith synonymously with the term in bad faith. 
context, good faith has suppletory and protective functions whose scope is defined by the express terms of the parties' contract. In contrast, as applied to the decisions of corporate directors, good faith focuses on directors' position as fiduciaries obliged to serve the interests of others." ${ }^{25}$ Accordingly, in corporate law the duty of good faith must be given a positive meaning.

It is neither necessary nor appropriate, however, to delineate that meaning by a single phrase. The duty of good faith is a general principle, and general principles often are delineated by baseline conceptions consisting of a cluster of elements. For example, the general principle of care is delineated by a baseline conception consisting of elements such as diligence and rationality. The general principle of loyalty is delineated by a baseline conception consisting of elements such as fairness and disclosure. The general principle of good faith is also delineated by a baseline conception consisting of a cluster of elements.

To begin with, good faith requires subjective honesty. Subjective honesty, in turn, requires several types of sincerity. A corporate manager must sincerely believe that his conduct is in the best interests of the corporation; that any statements he makes in his managerial capacity are truthful; and that his conduct is within the realm of decent behavior.

It is not enough, however, that a manager acts honestly in the sense that he acts sincerely. Many persons adopt belief-systems that allows them to sincerely conclude that their morally outrageous conduct is proper. This point is well put in a review by Mick LaSalle of the film Downfall, which concerns Adolph Hitler's final days. ${ }^{26}$ As LaSalle noted, the fact that "Hitler is portrayed as human made the film mildly controversial in America, as though that were the same as making him likeable." This, LaSalle pointed out, missed the value of the film, which is to remind us of "a lesson that simply can't be repeated enough - that absolute faith in one's virtue is not a commitment to virtuous behavior but a commitment to one's own will." Or, as Deborah De Mott puts it:

Wholly apart from these practical issues of proof, a standard for good faith that looks solely to directors' motives ignores the function to be served by the standard. As applied to directors' decisions, a standard of good faith tests directors' fidelity to the interests they may appropriately consider of serve. Subjective motivation and sincere belief are, at best, imprecise surrogates to measure fidelity. Directors, like other people, are capable of deceiving themselves about the point and effect of their actions.

25 DeMott, supra note 1, at 24.

26 Mick LaSalle, "Downfall", San Francisco Chronicle Datebook, August 7, 2005, at 28. 
Sincere self-deception is not responsive to the obligation to which directors, as fiduciaries, are subject. Fiduciary norms are stringent: they prohibit the fiduciary from creating interests in conflict with interests of the beneficiary protected by the relationship, and they deny a fiduciary the profit derived from a breach of duty even when the breach caused no demonstrable injury to the beneficiary. One explanation for this stringency is the persistent capacity of decisionmakers for sincere self-deception when self-interest is at stake. ${ }^{27}$

Accordingly, good faith in law includes objective as well as subjective elements. So, for example, in First Nat'l Bank v. F. C. Trebein Co. ${ }^{28}$ the court said "[G]ood faith in law ... is not to be measured by a man's own standard of right, but by that which [the law] has adopted and prescribed as a standard for the observance of all men in their dealings with each other."

In corporate law, as in law generally, the objective elements of good faith dominate the subjective element. For example, in In re Landmark Land Co. ${ }^{29}$ the court held that the defendants' deliberate action to circumvent the authority of a governmental agency constituted bad faith even if the defendants intended to and did act in interests of the best interests of the corporation. The objective baseline elements of good faith in corporate law are based in part on the meaning of good faith in common usage, as established in lay and legal dictionaries; in part on the meaning of good faith developed in various bodies of law, including corporate law; and in part on the basis of the reasonable expectations of shareholders and of the society at large. The duty of good faith in corporate law includes three such elements.

First, the duty of good faith in corporate law requires a manager not to violate generally accepted standards of decency applicable to the conduct of business. ${ }^{30}$ This element conforms to a standard dictionary definition of good faith, "compliance with standards of decency." 31

Second, the duty of good faith in corporate law requires a manager not to violate generally accepted basic corporate norms. ${ }^{32}$ This element is analogous

27 DeMott, supra note 1, at 22-23.

2852 N.E. 834, 837 (Ohio 1989).

2976 F. 3d 553 ( $4^{\text {th }}$ Cir. 1996).

30 See DeMott, supra note 1.

31 See American Heritage Dictionary 755 (4th ed. 2004).

32 Cf. E. Norman Veasey, "Corporate Governance and Ethics in the Post-Enron WorldCom Environment", 38 Wake Forest L. Rev. 839, 850-51 (2003) ("Today, the "utter failure' to follow the minimum expectations of the evolving standards of director conduct ... might ... raise a good-faith issue...."). 
to the definition of good faith in Article 2 of the Uniform Commercial Code, which provides that in the case of a merchant, good faith means honesty in fact and the observance of reasonable commercial standards of fair dealing. ${ }^{33}$

Third, the duty of good faith in corporate law requires a manager to have fidelity to his office. This element conforms to the definition of good faith in Black's Law Dictionary, which includes faithfulness to one's duty and obligation, and reflects the reasonable expectations of shareholders. ${ }^{34} \mathrm{By}$ office, in this context, I mean, a position of duty, trust, or authority in an organization. By fidelity to one's office, I mean an attempt to execute an office, and the role that the office implicates, in the manner in which execution of the office is reasonably to be expected, given the constitution of the office and of the organization in which the office is embedded.

The role of the baseline conception of the duty of good faith must be understood against a distinction between standards of conduct and standards of liability. ${ }^{35} \mathrm{~A}$ standard of conduct states how an actor should conduct a given activity or play a given role. A standard of review states the test that a court should apply when it reviews an actor's conduct to determine whether to impose liability on the actor. In many or most areas of law, these two kinds of standards tend to be conflated. For example, the standard of conduct that governs automobile drivers is that they should drive carefully, and the standard of review in a liability claim against a driver is whether he drove carefully. The conflation of standards of conduct and standards of review is so common that it is easy to overlook the fact that whether the two kinds of standards are or should be identical in any given area is a matter of prudential judgment. For a variety of reasons, in corporate law the standards of review and the standards of conduct pervasively diverge. ${ }^{36}$ For example, in the area of loyalty the general standard of conduct is that a manager who acts in his own self-interest should act fairly. However, a standard of review that is much easier for the manager to satisfy may be applied if a self-interested transaction has been approved by disinterested directors. Similarly, in the area of care the general standard of conduct is that a manager should act reasonably. How-

33 See, e.g., Cal. Commercial Code $\$ 2103(\mathrm{~b})$.

34 Black's Law Dictionary 713 (8th ed. 2004). See also, e.g., In Re Hicks, 7 B.R. 45, 47 (Bankr. N.D. Ala. 1987).

35 See Melvin A. Eisenberg, "The Divergence of Standards of Conduct and Standards of Review", 52 Fordham L. Rev. 437 (1993). That Article touched on the duty of good faith, but did so only briefly.

36 This divergence between standards of conduct and standards of review in corporate law was long implicit. The Model Business Corporation Act has now made this divergence explicit. Section 8.30 of the Model Act sets forth "Standards of Conduct" for Directors, while section 8.31 sets forth "Standards of Liability for Directors." (Emphasis added.) 
ever, if the manager's conduct satisfies the conditions of the business-judgment rule, the standard of review is whether the manager's judgment was rational, which is a much easier standard for the managers to satisfy.

Similarly, while the baseline conception of the duty of good faith is a standard of conduct, noncompliance with that conception does not in and of itself give rise to liability. Liability will arise only under specific obligations that instantiate the duty of good faith. In this respect, the duty of good faith operates like the duties of care and loyalty. Courts normally do not impose liability on a corporate manager simply on the ground that the manager acted without due care. Instead, they impose liability only on the ground that the manager violated a specific obligation that is based on the duty of care, such as the obligation to become properly informed before making a decision. Correspondingly, courts normally do not impose liability on a manager simply on the ground that the manager acted disloyally. Instead, they impose liability only on the ground that the manager violated a specific obligation that is based on the duty of loyalty, such as the obligation not to engage in a self-interested transaction at an unfair price.

The fact that the baseline conception of the duty of good faith is not a liability rule does not mean that the conception lacks legal significance. On the contrary, the baseline conception has three important roles in corporate law. First, the baseline conception is a legal standard of conduct.

Second, where good faith is a condition to the application of a statutory provision, the condition will not be satisfied if there has been a failure to comply with one or more of the elements of the baseline conception.

Third, the general baseline conception serves as a platform for more specific obligations that instantiate that conception, whose violation may give rise to liability.

To summarize, the elements of the baseline conception of the duty of good faith in corporate law are subjective honesty or sincerity, nonviolation of generally accepted standards of decency applicable to the conduct of business, nonviolation of generally accepted basic corporate norms, and fidelity to office. This baseline conception serves three functions. First, the baseline conception is a standard of conduct. Second, the elements of the baseline conception figure in determining whether a manager has satisfied a condition of good faith. Third, the general baseline conception provides a platform for more specific obligations. These more specific obligations, some of which will be discussed in Part V, serve to give further texture to the duty of good faith in cases where good faith operates as a condition, and may also serve as liability rules. 
To put this differently, when good faith operates as a condition, the courts should ask whether the manager has violated either an element of the baseline conception of the duty of good faith or a specific obligation that is based on that conception. When liability is at issue, however, the court should ask the narrower question, whether the manager has violated a specific obligation that instantiates the baseline conception.

\section{Normative considerations}

Part II of this Article briefly describes four reasons why the duty of good faith not only is but should be part of American corporate law. In this Part, I will develop those reasons in greater depth.

\section{The duty of good faith covers managerial conduct that is improper but does not fall within the duties of care or loyalty}

The duties of care and loyalty, as traditionally understood, have well-defined ambits. The duty of care requires a manager who is not self-interested to perform his duties in a manner that he reasonably believes to be in the best interests of the corporation, with a view to enhancing corporate profit and shareholder gain. In that connection, the standard of conduct under the duty of care (although not the standard of review) requires a manager to act reasonably - with due care - in informing himself concerning a proposed decision, and in making the decision itself. The duty of loyalty requires a manger to act fairly when he is interested in a transaction or a course of conduct. A manager is interested, for purposes of the duty of loyalty, when he, an associate, or a closely related family member has a financial interest in the transaction or in conduct. For example, section 1.23(a) of the ALI's Principles of Corporate Governance defines "interested," for purposes of the duty of loyalty, as follows:

A director ... or officer ... is "interested" in a transaction or conduct if either:

(1) The director or officer ... is a party to the transaction or conduct;

(2) The director or officer has a business, financial, or familial relationship with a party to the transaction or conduct, and that relationship would reasonably be expected to affect the director's or officer's judgment with respect to the transaction or conduct in a manner adverse to the corporation;

(3) The director or officer has a material pecuniary interest in the transaction or conduct ... and that interest ... would reasonably be expect- 
ed to affect the director's or officer's judgment in a manner adverse to the corporation ....

Similarly, section 8.60 of the Model Business Corporation Act defines a "director's conflicting interest transaction" to mean:

a transaction effected or proposed to be effected by the corporation ....

(i) to which ... the director is a party; or

(ii) respecting which ... the director had knowledge and a material financial interest known to the director: or

(iii) respecting which ... the director knew that a related person was a party or had a material financial interest.

In various important kinds of cases however, a manager's conduct is improper but either falls outside the spheres of the duties of care and loyalty, as those duties are traditionally conceived. An example is provided by Chancellor Chandler in Disney IV:

... [In the context of] an imperial CEO or controlling shareholder with a supine or passive board ... the concept of good faith may prove highly meaningful. The fiduciary duties of care and loyalty, as traditionally defined, may not be aggressive enough to protect shareholder interests when the board is well advised, is not legally beholden to the management or a controlling shareholder and when the board does not suffer from other disabling conflicts of interest, such as a patently self-dealing transaction. Good faith may serve to fill this gap and ensure that the persons entrusted by shareholders to govern Delaware corporations do so with an honesty of purpose and with an understanding of whose interests they are there to protect. $^{37}$

Other examples, which will be discussed in Part VI, include cases in which a manager knowingly causes the corporation to violate the law, lacks candor in a non-self-interested context, or acts out of improper nonfinancial motives. An important reason for the duty of good faith therefore is that this duty covers most important types of cases in which a manager's action, although improper, does not violate the duties of care or loyalty.

\section{Certain rules that limit the duties of care and loyalty should not and do not apply to conduct that lacks good faith}

Various rules limit a manager's accountability under the duties of care and loyalty. For example, a manager will not be liable for breach of the duty of

37 Id. at $\approx 192$ n. 487. 
care, even if he is negligent, if his conduct is protected by the business-judgment rule or a gross-negligence standard. In the case of the duty of loyalty, self-interested transactions may be insulated from effective judicial review if they are approved by a director's friends and colleagues on the board. Furthermore, injury to the corporation, or gain to the manager, are elements of a breach of those duties. So, for example, even if a manager normally employs a grossly negligent decision making process, he will not have violated the duty of care if the outcome is no worse than it would have been if he had been careful. Similarly, a director who sells a building that he owns to the corporation at a price that is at the very high end of the range of market prices will not be liable for violating the duty of loyalty.

These limiting rules should be and are inapplicable to conduct that violates the duty of good faith because of the high degree of wrongfulness that such conduct involves. Conduct that lacks good faith, such as knowingly causing the corporation to violate the law should not be protected by the businessjudgment rule or a gross-negligence standard, and should not be insulated from effective judicial review by the approval of a director's friends and colleagues. Furthermore, conduct that lacks good faith should be deemed improper whether or not injury to the corporation or gain to the manager is shown. For example, a manager who knowingly causes the corporation to break the law violates the duty of good faith even if breaking the law maximizes profits, and a manager who acts on the basis of an improper motive violates the duty of good faith even if his action fortuitously does not injure the corporation.

\section{The duty of good faith characteristically functions differently than the duties of care and loyalty}

The duty of good faith characteristically functions differently than the duties of care and loyalty. To understand this difference, it is useful to analogize to contracts. Contracts are constructed on the basis of two very different types of provisions - promises and express conditions. A promise is a commitment to perform in a designated manner. An express condition provides that a contracting party does not come under a duty to perform a promise unless and until some designated state of events occurs or fails to occur. Breach of a promise gives rise to liability. Nonfulfillment of a condition does not. Instead, nonfulfillment of a condition by one party relieves the other party of his duty to perform.

The duties of care and loyalty for the most part function as promises do; that is, they characteristically serve as bases of liability. In contrast, although the 
duty of good faith serves as a platform for certain liability rules, good faith much more commonly serves as a condition to the application of a rule that does not in itself impose liability, such as an indemnification provision or the business-judgment rule. Where the duty of good faith serves as a condition, failure to fulfill that duty does not in and of itself lead to liability. For example, a manager who is deprived of the benefit of the business-judgment rule because he lacked good faith typically is not liable simply for that reason. Rather, he is liable if and only if he violated the duty of care. Similarly, a manager who is deprived of the benefit of a shield provision is not liable simply for that reason: a shield provision applies only if the manager would be liable but for the shield. Just as conditions and promises are treated differently in contract law because they serve different functions, so the duty of good faith should be treated differently from the duties of care and loyalty because for the most part it serves a much different function than the latter duties do.

4. The duty of good faith provides the courts with a principled basis for developing new specific fiduciary obligations in response to social changes

The life of the law, including the life of corporate law, is in a constant state of change in response to social changes. Circumstances change, the social norms applicable to the conduct of business change, business practices change, concepts of efficiency and other issues of policy applicable to corporate law change. Sometimes, social changes indicate that an existing fiduciary obligation should be modified or cut back. An example is the widespread legislative adoption of exculpatory or shield provisions. Other times, social changes indicate that a new specific fiduciary obligation should be articulated because a type of conduct that was once regarded as proper is no longer so regarded. In some cases, the adoption of such an obligation can be justified by the duties of care or loyalty. In other cases, it cannot. In those cases, the duty of good faith often provides a principle that supports the adoption of the new obligation. ${ }^{38}$ An example is the emerging obligation of candor, which will be discussed in Part VI.

38 As Summers points out in connection with the duty of good faith in contract law: "[The function that good faith doctrines] perform furthers the most fundamental policy objectives of any legal system-justice, and justice according to law. By invoking good faith, ... it may be possible for a judge to do justice and do it according to law. Without legal resources of this general nature he might, in a particular case, be unable to do justice at all, or he might be able to do it only at the cost of fictionalizing existing legal concepts and rules, thereby snarling up the law for future cases. In begetting snarl, fiction may introduce inequity, unclarity or unpredictability. In addition, fiction can divert analytical focus ...". Summers, supra note 1, at 198-99. 


\section{Some specific obligations under the duty of good faith}

\section{The obligation not to knowingly cause the corporation to violate the law}

A well-established principle under the duty of good faith is that a manager may not knowingly cause the corporation to violate the law, even when it is rational to believe that the violation would maximize corporate profits and shareholder gain because the cost of the violation, consisting of the legal penalty and damage to reputation, multiplied by the likelihood of detection, is less than the expected profit from the violation. Like other obligations that fall under the duty of good faith, fulfillment of this obligation will often operate as a condition - for example, as a condition to indemnification. However, violation of this obligation also gives rise to liability.

The reason for the obligation not to knowingly cause the corporation to violate the law is as follows: A complex society in which individuals obeyed the law only because they feared prosecution could not thrive. For a complex society to thrive, the bulk of its members must internalize the moral obligation to obey the law. Similarly, given the dominance of organizations in complex societies, such a society could not thrive if individuals believed themselves free of a moral obligation to obey the law when they acted in an organizational rather than personal capacity.

Accordingly, there is a strong social interest in prohibiting managers from causing the corporation to knowingly disobey the law in the search of profits. This objective cannot be achieved solely by criminal and civil actions against the corporation. Where the corporation's violation is criminal, the violation will often go undetected or unprosecuted simply because the resources of police and prosecutors are very limited. Furthermore, the principle that organizations must obey the law is most likely to be internalized by the organization and its members if the principle is part of organizational law itself. Moreover, because the corporation is the primary wrongdoer, the probability that a manager who knowingly causes the corporation to violate the law will be made criminally or civilly liable for the corporation's act is very low, so an additional sanction is required to disincentive managers from engaging in such conduct.

A corporation is therefore obliged to obey the law, not only as a matter of criminal and regulatory law, but as a matter of corporate law. This obligation is reflected in section 2.01 of the ALI's Principles of Corporate Governance. Section 2.01(a) of the Principles provides that, with certain exceptions, "a corporation should have as its objective the conduct of business activities with a view to enhancing corporate profit and shareholder gain." Under section 2.01(b) however, "[e]ven if corporate profit and shareholder gain are not thereby enhanced, the corporation, in the conduct of its business ... [is] oblig- 
ed, to the same extent as a natural person, to act within the boundaries set by law...."

I will call the principle embodied in section 2.01(a) the profit-maximization principle, and the principle embodied in section 2.01(b)(1) the legal-conduct principle. The legal-conduct principle is exemplified in Illustration 7 to section 2.01(b)(1):

F Corporation is a publicly held corporation with annual earnings in the range of \$ 3-5 million. F hopes to be awarded a supply contract by $P$, a large publicly held corporation. The anticipated profits on the contract are $\$ 5$ million over a two-year period. A vice-president of $\mathrm{P}$ has approached Brown, the relevant corporate decisionmaker of $F$, with the suggestion that if $F$ pays the vice-president $\$ 20,000, F$ will be awarded the contract. Brown knows such a payment would be illegal, but correctly regards the risk of detection as extremely small. After carefully weighing that risk and the consequences of detection, Brown causes $F$ to pay the $\$ 20,000$. F's action involves a departure from the principle stated in $\$ 2.01(b)(1) .{ }^{39}$

Assume that the payment demanded by the vice-president of $P$, plus the present value of a fine and all other financial and reputational costs that might flow from the illegal payment, discounted by the likelihood of detection and enforcement, is less than the present value of the supply contract. On a profit-maximization analysis, A should pay the bribe. Under the legal-conduct principle, however, the bribe should not be paid. Instead, A should cause F to obey the legal rule that prohibits bribery. Cost-benefit analysis may very well factor into an authoritative determination whether a given type of conduct should be deemed legally wrongful. Once that determination has been made, however, the resulting legal rule normally represents a community decision that the conduct is wrongful as such. Violations of the rule cannot then be morally or socially justified on the ground that in a particular case the violator's financial gains would outweigh either its financial losses, or even general

39 Here is another illustration:

G Corporation owns and operates 15 plants that were traditionally non-union. For the last several years, Union $U$ has been attempting to organize G's workers, and has won elections at three of G's plants. Although $G$ does not have a good faith belief that the elections were invalid, it adopts a strategy of refusing to bargain at these three plants and harassing members, adherents, and supporters of $U$ at G's other 12 plants. The relevant corporate decisionmaker knows that the conduct violates the National Labor Relations Act, but believes that a long time will elapse before sanctions are imposed, and that the profit from this conduct will far exceed the cost of possible sanctions. G's action involves a departure from the principle stated in $\$ 2.01(\mathrm{~b})(1)$. 
social losses, except in those relatively rare cases where either the sanction under the relevant legal rule is properly regarded as a price, like parking overtime at a meter, or the norm of obedience to law is conventionally deemed inapplicable or counterbalanced by other norms, such as necessity. So, for example, in a well-known essay Milton Friedman denied that corporations have any social responsibility other than to increase profits, but also made clear that the pursuit of profits had to be conducted while conforming to the basic rules of society, including legal rules. ${ }^{40}$

Indeed, the legal-conduct principle is consistent with the profit-maximization principle. The profit-maximization principle states what the objective of the corporation should be. The legal-conduct principle does not modify that objective, but rather lays down the channels within which that objective may properly be realized. An analogy may be drawn to the rules of a game. An objective of playing a game is to win. Obeying the rules of a game is consistent with that objective, even when breaking the rules would make winning more likely. If a player asserted that she was justified in breaking the rules of a game because doing so maximized her chances of winning, we would say that she doesn't understand what it means to play a game. As with the rules of a game, so with the rules of law. A corporate actor who said that profit-maximization justifies causing the corporation to break the law wouldn't understand what law means and wouldn't understand what profit-maximization means.

Section 2.01 of the Principles of Corporate Governance concerns the objectives of the corporation, rather than the duties and liabilities of corporate managers. However, the principle reflected in that section also applies to corporate managers, for the same reasons. Accordingly, section 4.01(a) of the Principles states that "A director or officer has a duty to the corporation to perform the director's or officer's functions in good faith", and the Comment to this section makes clear that a manager who knowingly causes the corporation to violate the law is in breach of the duty of good faith:

... The duty of a director or officer to "perform the director's or officer's functions in good faith" includes the obligation to act consistently with $\$ 2.01 \ldots$

... [A] director or officer violates the duty to perform his or her functions in good faith if he or she knowingly causes the corporation to disobey the law.

40 Milton Friedman, "The Social Responsibility of Business Is to Increase its Profits", N.Y. TIMES, Sept. 13, 1970 (Magazine), at 33, 126. 
Similarly, the Comment to Model Business Corporation Act $\$ 8.31$ states:

Conduct involving knowingly illegal conduct that exposes the corporation to harm will constitute action not in good faith, and belief that decisions made (in connection with such conduct) were in the best interests of the corporation will be subject to challenge as well.

The rule embodied in the Comments to the Principles of Corporate Governance and the Model Business Corporation Act is well supported by case law. For example, in Roth $v$. Robertson, ${ }^{41}$ the managing director of a corporation that owned an amusement park caused the corporation to pay off persons who had threatened to complain to authorities that the park was unlawfully operating on Sundays. Undoubtedly, the director made these payments to maximize corporate profits. Moreover, the director could have rationally believed that the expected corporate profits from operating the amusement park on Sundays would exceed the possible cost of punishment to the corporation, discounted by the likelihood of detection and enforcement. Nevertheless, the court held that the director was liable to the corporation for the amount of the payoffs:

For reasons of public policy, we are clearly of the opinion that payments of corporate funds for such purposes as those disclosed in this case must be condemned, and officers of a corporation making them held to a strict accountability, and be compelled to refund the amounts so wasted for the benefit of stockholders .... To hold any other rule would be establishing a dangerous precedent, tacitly countenancing the wasting of corporate funds for purposes of corrupting public morals. ${ }^{42}$

In Abrams v. Allen, ${ }^{43}$ plaintiffs brought a derivative action against the directors of Remington Rand, alleging that the directors had illegally closed and relocated corporate plants, and curtailed production, to intimidate and punish employees for their involvement in a labor dispute, in violation of the New York Labor Law and the National Labor Relations Act. ${ }^{44}$ Undoubtedly, the directors engaged in this conduct to maximize corporate profits. More-

4164 Misc. 343, 118 N.Y.S. 351 (App. Div. 1909).

$42 I d$. at 346,118 N.Y.S. at 353.

43297 N.Y. 52, 74 N.E.2d 305 (1947).

$44 \mathrm{Id}$. at 56,74 N.E.2d at 306-07. The court added, "That violation of a federal statute is the basis of the breach of fiduciary duty and that therefore the court is required to interpret the federal statute has not deterred New York courts from entertaining such suits against directors." See Knopfler v. Boben, 15 A.D.2d 922, 225 N.Y.S.2d 609 (2d Dept. 1962); cf. Simon v. Socony Vacuum Oil Co., 179 Misc. 20238 N.Y.S.2d 270 (Sup.Ct.1942). 
over, the directors could have rationally believed that the expected corporate profits from fighting unionization would exceed the possible cost of punishment to the corporation, discounted by the likelihood of detection and enforcement. Nevertheless, the court held that proof of the plaintiff's allegation could sustain recovery against the directors. ${ }^{45}$

In Miller v. American Telegraph and Telephone Co. ${ }^{46}$ AT\&T had failed to collect an outstanding debt of $\$ 1.5$ million owed by the Democratic National Committee for communications services that AT\&T had provided during the 1968 Democratic National Convention. Plaintiffs brought a derivative action against AT\&T's directors, on the ground that the failure to collect the debt was a corporate contribution to the Democratic Party, in violation of a thenexisting federal prohibition on corporate campaign contributions, 18 U.S.C. $\$ 610$. Undoubtedly, the board took this action to maximize corporate profits. Moreover, the board could have rationally believed that the expected corporate profits from making a contribution to the Democratic Party would exceed the possible punishment, discounted by the likelihood of detection and enforcement. Nevertheless, the court held that on the facts stated in the complaint, the directors would be liable:

Had plaintiffs' complaint alleged only failure to pursue a corporate claim, application of the sound business judgment rule would support the district court's ruling that a shareholder could not attack the directors' decision. ... Where, however, the decision not to collect a debt owed the corporation is itself alleged to have been an illegal act, different rules apply. When New York law regarding such acts by directors is considered in conjunction with the underlying purposes of the particular statute involved here, we are convinced that the business judgment rule cannot insulate the defendant directors from liability if they did in fact breach 18 U.S.C. $\$ 610$, as plaintiffs have charged. ${ }^{47}$

Similarly, in Metro Commun. Corp. BVI v. Advanced Mobilecomm Techs. Inc., ${ }^{48}$ the Delaware Chancery Court held that "Under Delaware law, a fiduciary may not choose to manage an entity in an illegal fashion, even if the fiduciary believes that the illegal activity will result in profits from the entity." In Guttman v. Jen-Hsuan Huang," another Delaware Chancery

4564 Misc. 2 d at 55,74 N.E.2d at 306.

46507 F.2d 759 (3d Cir. 1974).

47 Id. at 762 .

48854 A.2d 121, 131 (Del. Ch. 2004).

49823 A.2d 492 (Del. Ch. 2003). 
Court case, the court also held that causing the corporation to violate the law violates a manager's fiduciary duty. ${ }^{50}$

A manager who knowingly causes the corporation to violate the law is liable to the corporation for any losses the corporation incurs as a result of the legal violation, such as fines. Furthermore, the amount of the manager's liability should not be offset by profits that the corporation made as a result of the violation, because such an offset would be contrary to the purpose of imposing liability. This position is embodied in section 7.18(c) of the Principles of Corporate Governance, which provides that a manager's liability arising out of a wrongful transaction may not be offset by gains to the corporation that arose out of the same transaction if the offset would be contrary to public policy. This rule is exemplified as follows:

A derivative action is brought to require a corporate official of XYZ Corporation to account to the corporation for $\$ 200,000$ in legally questionable overseas political contributions. The defendant admits the payments, but seeks to defend on the basis that in prior years other such payments had produced profitable contracts.... Even if the offsets arise out of the same transaction, the court should decline to permit offsets that it determines are contrary to an established public policy. ${ }^{51}$

A manager's obligation not to knowingly cause the corporation to violate the law has traditionally and properly been founded on the duty of good faith. ${ }^{52}$ Indeed, the obligation cannot be founded on the duties of care and loyalty. A manager who knowingly causes the corporation to violate the law will seldom violate the duty of loyalty, because typically the manager does not

50 See also, e.g., H. R. Plate v. Sun-Diamond Growers, 225 Cal. App.3d 1115, 1125 (1990) ("For example, corporate executives who participate in a deliberate price-fixing conspiracy with competing firms could not be found to have acted in good faith, even though they may have reasonably believed that a deliberate flouting of the antitrust laws would increase the profits of the corporation.") (quoting H. Marsh, California Corporation Law $\$ 9.42$ (2d ed.); Wilshire Oil Co. v. Riffe, 409 F.2d $1277,1283-86\left(10^{\text {th }}\right.$ Cir. 1969) (fiduciary duty owed to the corporation by employees whose antitrust violations subjected the corporation to civil and criminal liability); Di Tomasso v. Loverro, 250 App.Div. 206, 209, 293 N.Y.S. 912, 916-17, aff'd mem., 276 N.Y. 551, 12 N.E.2d 570 (1937) (injunction granted and directors liable for damages, in derivative action, where they knew, or should have known, the contract was in restraint of trade); Arsht, "The Business Judgment Rule Revisited", 8 Hofstra L. Rev. 93, 129-30 (1979) ("Bad faith may preclude the application of the business judgment defense where directors knowingly violate a statute or comparable expression of public policy, even if such a violation is undertaken in the corporation's best interests).

51 ALI, Principles of Corporate Governance, supra note $10, \$ 7.18$, Illustration 4.

52 See p. 20-21, supra. 
engage in self-interested conduct, and will seldom violate the duty of care, because typically the manager rationally believes that the illegal conduct will serve the end of profit-maximization.

\section{The obligation of candor}

Another set of obligations that are based on the duty of good faith consist of obligations of candor in various contexts not involving self-interest. ${ }^{53}$ (I use the term candor in its broadest sense, to mean the "state or quality of being frank, open, and sincere in speech or expression." ${ }^{54}$ ) For present purposes, the obligation of candor has two aspects. First, managers have an obligation not to make intentionally or recklessly false or misleading statements in their managerial capacity. I will refer to this aspect of candor as the obligation not to mislead. Second, managers have an obligation not to intentionally or recklessly fail to inform other managers or corporate organs (including the body of shareholders) of information that is known by the manager to be material to the other managers or the corporate organs in making decisions or discharging their duties. I will refer to this aspect of candor as the obligation to duly inform. Although the obligations not to mislead and to duly inform shade into each other, they differ in an important way. The obligation not to mislead only addresses the issue how a manager should act if he makes a statement. In contrast, the obligation to duly inform imposes a positive duty on managers to make certain statements. A manager's obligation of candor is not limited to ensuring that what he chooses to say is true. Rather, in appropriate cases a manager must step forward and say what ought to be said.

I will discuss the obligation of candor, even where self-interest is not involved, in three contexts: communication between the board and the shareholders; communication among members of the board; and communication by officers to the board and to other officers.

\section{a) The board's obligation of candor}

\section{aa) The obligation not to mislead}

It has long been the law that when directors request shareholder action they may not knowingly make misleading statements concerning the action. ${ }^{55}$

53 See Sale, supra note 1, at 487-88.

54 Random House Dictionary of the English Language 305 ( $2 \mathrm{~d}$ ed. 1987).

55 See, e.g., Malone v. Brincat, 722 A.2d 5 (Del. 1998) ("This Court has held that a board of directors is under a fiduciary duty to disclose material information when seeking 
Suppose, however, that the directors knowingly make misleading statements to the shareholders without requesting shareholder action.

If the corporation is subject to reporting requirements under the Securities Exchange Act, and the statements are made in an SEC filing, the directors will have violated federal law. Even if those conditions are not satisfied, a knowingly misleading statement may give rise to liability under Rule 10b-5, which makes it unlawful to make any untrue statement of a material fact, or to omit a material fact necessary to make statements not misleading, in connection with the purchase or sale of securities. But Rule $10 \mathrm{~b}-5$ is hedged in a variety of ways, one of which is that only a purchaser or a seller may bring a private action under that Rule. The issue therefore arises whether shareholders who are not purchasers or sellers can bring suit under corporation law against directors who have knowingly made misleading statements to the shareholders, on the ground that the directors have violated their fiduciary duty.

That issue was addressed in Malone v. Brincat, ${ }^{56}$ decided by the Delaware Supreme Court in 1999. Mercury Finance was a publicly traded corporation. Plaintiffs, who had been Mercury shareholders since 1993, brought a class action against Mercury's directors on the ground that the directors had knowingly disseminated false information by overstating Mercury's earnings, financial performance, and shareholders' equity. For example, according to the complaint, in 1995, Mercury reported earnings of $\$ 99$ million when in fact earnings were only $\$ 78$ million. In 1996, Mercury reported earnings of $\$ 121$ million when in fact earnings were only $\$ 57$ million. At year-end 1996, Mercury reported that shareholders' equity was $\$ 353$ million when in fact it was not more than $\$ 263$ million. All this inaccurate information was included in communications that Mercury's directors made to the shareholders.

The directors moved to dismiss the complaint, arguing that under the circumstances alleged they had not violated Delaware corporate law. Applying Chancery Court precedent, the Vice Chancellor granted the motion and dis-

shareholder action."); Loudon v. Archer-Daniels-Midland Co., Del. Supr., 700 A.2d 135, 137-38 (1997) (“... Delaware law of the fiduciary duties of directors ... establishes a general duty to disclose to stockholders all material information reasonably available when seeking stockholder action ..."); Arnold v. Society for Savings Bancorp, Inc., Del.Supr., 650 A.2d 1270, 1277 (1994) (a fiduciary disclosure obligation "attaches to proxy statements and any other disclosures in contemplation of shareholder action"); Stroud v. Grace, Del.Supr., 606 A.2d 75, 84 (1992) ("directors of Delaware corporations are under a fiduciary duty to disclose fully and fairly all material information within the board's control when it seeks shareholder action"). See also, e.g., Alessi v. Beracha, 849 A.2d 939 (2004).

56772 A.2d 5 (Del. Supr. 1999). 
missed the complaint with prejudice, on the ground that directors had no duty of candor under Delaware law except when they were requesting shareholder action. The Delaware Supreme Court, however, held that directors do have a duty to communicate honestly with shareholders even outside the context of a request for shareholder action:

... The director's fiduciary duty to both the corporation and its shareholders has been characterized by this Court as a triad: due care, good faith, and loyalty. That tripartite fiduciary duty does not operate intermittently but is the constant compass by which all director actions for the corporation and interactions with its shareholders must be guided....

... Whenever directors communicate publicly or directly with shareholders about the corporation's affairs, with or without a request for shareholder action, directors have a fiduciary duty to shareholders to exercise due care, good faith and loyalty. It follows a fortiori that when directors communicate publicly or directly with shareholders about corporate matters the sine qua non of directors' fiduciary duty to shareholders is honesty....

The issue in this case is not whether Mercury's directors breached their duty of disclosure. It is whether they breached their more general fiduciary duty of loyalty and good faith by knowingly disseminating to the stockholders false information about the financial condition of the company. The directors' fiduciary duties include the duty to deal with their stockholders honestly. ${ }^{57}$

Although the Court in Malone v. Brincat referred to both loyalty and good faith - and earlier in its opinion, referred to care - the board's obligation not to mislead in communications to the shareholders that do not involve a request for shareholder action is best explained by the duty of good faith. The duty of loyalty is not a satisfactory basis for the obligation, because the board may violate the obligation not to mislead even if it not self-interested. The duty of care is not a satisfactory basis for the obligation, because under given circumstances the board may make a rational decision that lack of candor is profit-maximizing and best protect the wealth of existing shareholders. In contrast, the duty of good faith does provide a basis for the obligation. First, a board that knowingly makes false statements to the shareholders acts dishonestly. Second, in knowingly making false statements to the shareholders, directors lack fidelity to their office, because shareholders have a reasonable expectation of truthful communication by the board.

57 Id. at 10. 
This leaves the issue of remedy. In some cases, misleading statements by the board may cause injury to the corporation - for example, as a result of repercussions when the truth comes out. This would be especially true if the corporation transacts in markets in which reputations are important, such as credit markets. In Malone v. Brincat, the plaintiffs alleged that as a result of the board's misleading statements the corporation had lost $\$ 2$ billion, comprising most or all of its value. The Delaware Supreme Court pointed out that such a loss would constitute an injury to the corporation; therefore, a suit based on the loss would have to be brought as a derivative action, preceded by a demand on the board; and the plaintiffs had neither made a pre-suit demand nor shown why a demand should be excused. Accordingly, the Court agreed that the complaint should be dismissed. However, the Court held that the plaintiffs should be permitted to replead a derivative claim, together with a request for any damage or equitable remedy sought on behalf of the corporation. The Court also held that the plaintiffs should have the opportunity to assert any individual cause of action, and to articulate a remedy that was appropriate on behalf of either the named plaintiffs individually or a properly recognizable class. In this connection, the Court referred to the possible remedies of injunctive relief, judicial removal of directors, or the disqualification of directors. ${ }^{58}$ This range of remedies dramatically illustrates that violation of the duty of good faith can have significant consequences apart from the possibility of liability for damages.

\section{bb) The obligation to duly inform}

If a corporation's securities are registered under section 12 of the Securities Exchange Act, the federal Proxy Rules require the board to provide the shareholders with extensive information concerning major transactions that require shareholder approval. However, the overwhelming bulk of corporations, including many publicly held corporations, are not subject to the Proxy Rules, and few if any state statutes require the board to provide the shareholders with material information concerning such transactions. The Delaware courts, at least, have filled part of the gap by making clear that the board has

58 The Court stated that it was expressing no opinion whether these remedies could be asserted in Malone itself, because that relief had not been sought in the complaint.

Another possible individual or class claim, in this context, would be a suit for damages by shareholders who refrained from selling in reliance on the director's false statements. Although the plaintiff in a private action under Rule $10 \mathrm{~b}-5$ must be either a purchaser or a seller, in Small v. Fritz, 132 Cal. Rptr. 2d 490 (Cal. 2003), the California Supreme Court held that a shareholder who continued to hold stock in a corporation in reliance on the board's knowingly misleading statements could sue the directors for fraud under state law. 
an obligation to duly inform the shareholders when the board requests a shareholder vote in such cases. Vice Chancellor Jacobs (as he then was) addressed this issue in Turner $v$. Bernstein, ${ }^{59}$ which involved an arm's-length merger of unaffiliated corporations in which the shareholders of one corporation were provided with virtually no information. Drawing on a large number of decisions, ${ }^{60}$ Vice Chancellor Jacobs stated:

The fiduciary duty of disclosure flows from the broader fiduciary duties of care and loyalty. That disclosure duty is triggered (inter alia) where directors ... present to stockholders for their consideration a transaction that requires them to cast a vote and/or make an investment decision, such as whether or not to accept a merger or demand appraisal. Stockholders confronted with that choice are entitled to disclosure of the available material facts needed to make such an informed decision. Specifically, in the merger context, the directors of a constituent corporation whose shareholders are to vote on a proposed merger, have a fiduciary duty to disclose to the shareholders the available material facts that would enable them to make an informed decision, pre-merger, whether to accept the merger consideration or demand appraisal.

In a later decision in the case, Vice-Chancellor Strine said, "In his earlier opinion ..., Vice Chancellor Jacobs succinctly stated the pertinent principles of law relevant to whether the defendant directors breached their fiduciary duties by providing the GenDerm stockholders with deficient disclosures." Vice Chancellor Strine added:

In Skeen v. Jo-Ann Stores, Inc., [750 A.2d 1170 (Del. Supr. 2000)] the Supreme Court recently confirmed Vice Chancellor Jacobs's view of the applicable standard, stating:

In this appeal we consider the adequacy of corporate disclosures to minority stockholders who were "cashed out" in a merger approved by the majority stockholder. The minority stockholders complain that they were not given enough financial information to decide whether to accept the merger consideration or seek appraisal. They say, in essence, that the settled law governing disclosure requirements for mergers does not apply, and that far more valuation data must be disclosed where, as here, the merger decision has been made and the only decision for the minority is whether so seek appraisal. We hold that there is no different standard for appraisal decisions. Directors must disclose all material facts within their control that a reasonable stockholder

59 Tumer v. Bernstein [I], 1999 WL 66532 (Del. Ch. 1999).

60 Turner v. Bernstein [II], 776 A.2d 530 (Del. Ch. 2000). 
would consider important in deciding how to respond to the pending transaction. ${ }^{61}$

Although Vice Chancellor Jacobs rested the board's obligation to duly inform in such cases on the duties of care and loyalty, those duties do not adequately explain the obligation, at least as they are traditionally understood. The duty of loyalty does not explain the obligation to duly inform, because that obligation applies even if the directors are not self-interested in the proposed transaction. The duty of care does not explain the obligation, because a failure to duly inform the shareholders does not run counter to the idea of profit-maximization. (It is true that when an obligation exists, a failure to duly perform the obligation may be a breach of the duty of care, but the existence of an obligation must precede the duty to perform it carefully.) The duty of good faith does explain the board's obligation to duly inform, because fidelity to office requires the board to satisfy the shareholders' reasonable expectations that the board will provide them with information that is known by the board to be material to a decision that the board requests the shareholders to make.

Of course, not every failure to duly inform violates the duty of good faith, just as not every noncompliance with law violates the duty of good faith. ${ }^{62}$ A failure to inform, like noncompliance with law, will violate the duty of good faith only if it is intentional or reckless. ${ }^{63}$

\section{b) Communication among directors}

Another context in which candor is required concerns communication by an individual director to the whole board. In this section, I will take it as a prem-

61 Turner v. Bernstein II, 776 A.2d at 542 (emphasis added by Vice Chancellor Strine.) See also, e.g., Frank v. Arnelle, 725 A.2d 441, 1999 WL 89284 (Del. Supr. 1999). Although the Delaware cases concerning transactional disclosure to the shareholders are sometimes framed in terms of the exercise of appraisal rights, for present purposes there is no reason in principle to distinguish between the exercise of appraisal rights and voting rights, and in Tumer $v$. Bernstein, Vice Chancellor Jacobs explicitly stated that disclosure was required in connection with both voting and appraisal rights.

62 See, e.g., Arnold v. Society for Savings Bancorp., 650 A.2d 1270, 1288 (Del. Supr. 1994) (directors did not lose protection of a shield provision on the ground of faulty disclosure where the single disclosure violation "was consistent with a good faith omission").

63 See Jobnson v. Wagner, 2003 WL 1870365 at $* 10$ (Del. Ch. 2003) ("If [Wagner had knowledge of the buyout proposal] and intentionally or recklessly failed to disclose such information Wagner would have breached his fiduciary duties"); Jobnson v. Shapiro, 2002 WL 31438477 at $* 8$ (Del. Ch. 2002) ("If Wagner intentionally failed to disclose, or was reckless in his failure not to disclose material information known on or before September 28, 1999 about the buyout proposal to Garden Ridge stockholders, then $\$ 102(b)(7)$ does not save him as a matter of law"). 
ise that individual directors, when communicating to the board, have an obligation not to mislead, and I will focus instead on an individual director's obligation to duly inform.

In the case of individual directors, the rule that should and almost certainly would be applied is that a director must duly inform the board of all material facts that he knows are relevant to the board's decisionmaking and monitoring responsibilities, even when he is not self-interested. This rule has now been explicitly embodied in section 8.31 (c) of the Model Business Corporation Act:

In discharging board or committee duties a director shall disclose, or cause to be disclosed, to the other board or committee members information not already known by them but known by the director to be material to the discharge of their decision-making or oversight functions ....

Again, the obligation to duly inform in this context is not explained by the duty of loyalty, because a director who withholds information may not act for reasons of self-interest. It is also not explained by the duty of care, because a director may withhold information in the reasonable belief that if he provides the information it might lead the board to make a decision that is not profit-maximizing. In contrast, the obligation to duly inform in this context is explained by the duty of good faith, because it springs from the requirement of fidelity to the director's office. The board is a collegial body, and the office of director entails an obligation to promote the board's decisionmaking and monitoring functions by duly informing the director's colleagues of facts that the director knows are relevant to discharge of those functions.

\section{c) Communication by officers}

A particularly important aspect of the obligation of candor concerns communication by officers.

One context in which officers have an obligation of candor involves the provision of information by officers to the board that bears on a proposed corporate action. When board approval is needed for a corporate action, the nonmanagement directors will be almost wholly dependent on the corporation's officers for the information on which their decision should be based. The officers, however, may spin the information they provide, to push the board toward a decision that the officers believe to be best for the corporation. Essentially, this is a special case of the more general problem presented by asymmetric information within a hierarchal organization. The problem is well described by Milgrom and Roberts:

We take it as given that some of the information that is important for the organization to make good decisions is not directly available to those 
charged with making the decisions. Instead, it is lodged with or producible only by other individuals or groups that are not empowered to make the decisions but may have a direct interest in the resulting outcomes....

In such situations, the members of the organization may have an incentive to try to manipulate the information they develop and provide in order to influence decisions to their benefits. Such manipulation can take many forms, ... [including] presenting the information in a way that accentuates the points supporting the interested party's preferred decision and then insisting on these points at every opportunity. ${ }^{64}$

The major concern in this area is not that officers will exploit informational asymmetry to benefit themselves by lining their own pockets in self-dealing transactions. Instead, the major concern is that the executives will attempt to herd the board toward action that the executives believe is in the corporation's best interests. As Milgrom and Roberts point out, "[the directors of a firm may have the final say on whether a new plant will be built but only the division whose products will be made in the plant can generate important parts of the relevant information on the likely profitability of the new facility." 65

An officer who provides some information while knowingly holding back other information, or who spins information, violates the obligation not to mislead. An officer also has an obligation to duly inform. Officers are a special class of agents, and the rule has long been established in agency law that agents have a duty to duly inform their principals. Restatement (Second) of Agency $\$ 381$ provided that an agent must "give his principal information which is relevant to affairs entrusted to him and which, as the agent has notice, the principal would desire to have." ${ }^{66}$ Similarly, Restatement (Third) of Agency $\$ 8.11$ provides that "An agent has a duty to use reasonable effort to provide the principal with facts that the agent knows ... when ... the agent knows or has reason to know that the principal would wish to ... have the facts. ..." ${ }^{167}$ The corporate-law counterpart of this rule has now been explicitly adopted in section 8.40(b)(1) Model Business Corporation Act:

64 Paul Milgrom \& John Roberts, "An Economic Approach to Influence Activities in Organizations”, 94 Am. J. Soc. S 154, S 156-57 (Supp. 1988) (footnote omitted); see also Paul Milgrom \& John Roberts, "Relying on the Information of Interested Parties", 17 Rand J. Econ. 18 (1986).

65 Milgrom \& Roberts, “An Economic Approach”, supra note 64, at S 156.

66 Restatement (Second) of Agency $\$ 381$ (1958).

67 Restatement (Third) of Agency $\$ 8.11$ (Tent. Draft No. 6, 2005). Restatement Third was approved at the ALI's 2005 annual meeting, but has not yet been published.

For a leading analysis of the duty of candor in corporate law, against the background of agency law, see Donald C. Langevoort, "Agency Law Inside the Corporation: Problems of Candor and Knowledge”, 71 U. Cin. L. Rev. 1187 (2003). 
(b) The duty of an officer includes the obligation:

(1) to inform the superior officer to whom, or the board of directors or the committee thereof to which, the officer reports of information about the affairs of the corporation known to the officer, within the scope of the officer's functions, and known to the officer to be material to such superior officer, board or committee. ...

This rule should and undoubtedly would be applied to corporate officers even by courts in non-Model Act jurisdictions. Indeed, one explanation of the result in the famous case of Smith v. Van Gorkom ${ }^{68}$ - or more accurately, one explanation of the imposition of liability on Van Gorkom, the CEO of Transunion, the corporation in that case - is that Van Gorkom violated his obligation of candor by holding back important information from the board in connection with a cash-out merger. For example, Van Gorkom did not disclose to the board the shaky methodology by which he had arrived at the price of $\$ 55$ per share for corporation, or the fact that Trans Union's CFO had concluded that in a leveraged buy-out the price range for Trans Union's stock would be $\$ 55-\$ 65$ per share.

There are other important contexts, besides board decisionmaking, in which officers owe an obligation to duly inform.

One of these contexts is providing the board with material information that is relevant to the board's duty to monitor.

A related context, which has been emphasized by Donald Langevoort, concerns providing the board with material information about important risk factors in the corporation's business:

Extraordinary forms of risk-taking are, by black-letter corporate law doctrine, for the board in any event. But even to carry out its monitoring function, the board must gain a fair sense of the aggregate level of risk assumed by the firm. Especially in today's business environment, where sophisticated tools for both hedging and assuming risk abound, there is a temptation to assume greater risk in order to satisfy perceived pressures whether from the marketplace or the board itself - to generate returns. Thus it is risk-related information that is the underdeveloped substance of the duty of candor we are describing. When risk is hidden, CEO's can play out "last period" strategies - taking more aggressive steps as the company's performance lags (or more likely, as the CEO fears that it is about to lag) because he or she fears that termination is a real possibility once 
that subpar performance becomes clear to the board. Risk-related information is also important to the board because it allows board members to second-guess the CEO's risk perceptions, which are likely to be colored by an optimistic bias.

An officer's obligation to duly inform the board of material information that he knows or has reason to know the board would desire to have is paralleled by an obligation to duly inform his superiors of such information. An officer also has an obligation to duly inform appropriate superior officers or corporate organs of material violations of law or breaches of duty by other officers, or by employees or agents of the corporation, which the officer believes have occurred or are likely to occur. The obligation to duly inform in this context is also explicitly imposed by section 8.41 (b)(2) of the Model Business Corporation Act:

(b) The duty of an officer includes the obligation ....

(2) to inform his or her superior officer, or another appropriate person within the corporation, or the board of directors, or a committee thereof, or any actual or probable material violation of law involving the corporation or material breach of duty to the corporation by an officer, employee, or agent of the corporation, that the officer believes had occurred or is likely to occur.

In agency law, the agent's obligation of candor is not categorized as part of either the agent's duty of care or duty of loyalty ${ }^{69}$ Neither can it be so characterized in corporate law. An officer's obligation of candor is not based on the duty of loyalty, because typically an officer will have no pecuniary selfinterest in providing or withholding information. The duty of care also does not provide a basis for this obligation, because typically when an officer violates this obligation, it is because he rationally believes that doing so is in the corporation's best interest. For example, in the Milgrom \& Roberts newplant hypothetical, the officers may rationally believe that building the new plant is the best decision, but that if all the material information was given to the board, the board might erroneously decide not to build the plant. Similarly, in the case of risk elements, an officer might withhold information from the board because he rationally believes that the board is unduly risk-averse. And an officer might fail to report others' violations of law and breaches of duty because he rationally believes that the wrongdoer was motivated by his perception of the corporation's best interests, and did not harm the corporation, and that disciplining the wrongdoer would itself harm the corporation.

69 See Restatement Second Chapter 13, Topic 1, Title B ("Duties of Service and Obedience"); Restatement Third Chapter 8, Topic 1, Title B ("Duties of Performance"). 
The duty of good faith does explain an officer's obligation of candor. ${ }^{70}$ An officer who makes misleading or skewed statements is insincere and dishonest, and lacks fidelity to his office. The board is entitled to have all material information that is relevant to its monitoring obligation, and to any decisions that the board is either required or chooses to make. The role of officers in such cases is to present the material facts, and present them fairly, not to spin the facts with the objective of leading the board in a certain direction that the officers believe is in the corporation's best interest. The officers may properly seek to achieve that objective only by reasoned persuasion. The board has the right to make decisions that the officers believe are wrong. An officer who fails to duly inform violates the duty of good faith. The same is true of an officer's superiors. Generally accepted basic corporate norms require officers to duly inform others within the corporation of information that is known to be material to the discharge of the others' duties and responsibilities. Fidelity to office requires an officer to be forthcoming with facts that come to his knowledge and that his office obliges him to pass on. Failure to duly inform may also be viewed as a lack of sincerity, because an actor who is charged with a duty to speak, and does not do so, acts insincerely.

Again, this leaves the issue of remedy. If the board is led to make a bad decision by the officers' breach of the obligation of candor, in principle the officers could be made liable for any losses resulting from the decision. In practice, however, causation in such cases would often, perhaps invariably, be difficult to prove. Alternative remedies are suggested by the Comment to section 8.42 of the Model Business Corporation Act, which points out that "deficient performance of duties by an officer, depending on the facts and circumstances, will normally be dealt with through intracorporate disciplinary procedures, such as reprimand, adjustment of compensation, delayed promotion, demotion, or discharge."71

\section{Impermissible motives}

Occasionally, a corporate manager engages in conduct in his managerial capacity that is based on a motive that although not pecuniary is self-regarding

$70 \mathrm{Cf}$. Langevoort, supra note 67, at 1203 ("[W] hat is the categorical basis for the duty of candor? Clearly, it is not part of the duty of care, which deals with negligent or unintentional misconduct. Nor is it really the duty of loyalty .... The intracorporate duty of candor is a separate and distinct kind of obligation, and ought to be recognized as such. At the same time, however, those wanting to stay within convention could make a good argument that it is an integral part of the duty of good faith, which is often mentioned as one of the three kinds of fiduciary obligations officers and directors owe under Delaware law.").

71 Model Bus. Corp. Act $\$ 8.42 \mathrm{cmt}$. (1999). 
(hereafter, an "impermissible motive"). Conduct based on such a motive violates the duty of good faith; as Chancellor Allen stated in In re RJR Sharebolders' Litigation, ${ }^{72}$ a manager does not act in good faith if he is motivated by "hatred, lust, envy, revenge, or ... shame or pride." Hatred, envy, and revenge may not often figure as managerial motives in publicly held corporations, but may frequently figure in closely held corporations. Lust or love may occasionally figure even in publicly held corporations, as where an executive hires or promotes a lover.

\section{Substantial disregard of responsibilities}

Managers sometimes disregard their responsibilities. Such disregard will almost always constitute a violation of the duty of care (although the manager may be insulated against liability by the business-judgment rule, a gross-negligence standard of review, or a shield provision in the corporation's certificate of incorporation). In some cases, however, the magnitude of the disregard rises to so high a level that the manager also violates the duty of good faith, because disregard of responsibilities at that level constitutes a lack of fidelity to one's office, violates generally accepted basic corporate norms, and, usually, is dishonest in the sense that the manager does not sincerely believe that he is acting properly. A number of important recent cases have so held - in particular, In re Caremark International Inc. Derivative Litigation, ${ }^{73} \mathrm{McCall} v$. Scott, ${ }^{74}$ In re Abbott Laboratories Derivative Shareholders Litigation, ${ }^{75}$ In re Emerging Communications Sharebolders Litigation, ${ }^{76}$ and Disney $I I I^{77}$ and $I V .^{78}$

Caremark, decided by Chancellor Allen in 1996, concerned disregard of the board's duty to install monitoring and information systems. Caremark Corporation was a health-care provider. A substantial portion of its revenues was derived from payments by Medicare and Medicaid. These payments were subject to the federal Anti-Referral Payments Law, which prohibited healthcare providers from making payments to third parties - primarily physicians to induce referrals of Medicare or Medicaid patients.

721989 WL 7036 (Del. Ch. 1989).

73 In re Caremark Int'l Inc. Derivative Litig., 698 A.2d 959 (Del. Ch. 1996).

74239 F.3d 808 ( $6^{\text {th }}$ Cir. 2001), amended, 250 F.3d 997 ( $6^{\text {th }}$ Cir. 2001).

75325 F.3d 795 ( $7^{\text {th }}$ Cir. 2003).

762004 WL 1305745 (Del. Ch. 2004).

77825 A.2d 275 (Del. Ch. 2003).

782005 WL 2056651 (Del. Ch. 2005). 
From its inception, Caremark entered into "consultation agreements" with, and made research grants to, physicians who then prescribed or recommended Caremark to their Medicare patients. Based on these agreements and grants, Caremark was indicted for violating the Anti-Referral Payments Law. Caremark pleaded guilty, agreed to pay civil and criminal fines, and reimbursed various private and public parties. In all, Caremark was required to make payments of approximately $\$ 250$ million as a result of its illegal conduct.

Derivative actions based on these payments were brought against Caremark's directors, and settled. The issue in Caremark itself was whether the settlements should be judicially approved. That issue, in turn, depended in part on the nature of the board's duty, if any, to install information and reporting systems. Chancellor Allen stated that it would "be a mistake to conclude that ... corporate boards may satisfy their obligation to be reasonably informed concerning the corporation, without assuring themselves that information and reporting systems exist in the organization that are reasonably designed to provide to senior management and to the board itself timely, accurate information sufficient to allow management and the board, each within its scope, to reach informed judgments concerning both the corporation's compliance with law and its business performance." 79 Rather, he said, "a director's obligation includes a duty to attempt in good faith to assure that a corporate information and reporting system, which the board concludes is adequate, exists ...." 80

As to when a failure of directors to assure themselves that appropriate information and reporting systems are in place constitutes a lack of good faith, Chancellor Allen opined that "only a sustained or systematic failure of the board to exercise oversight - such as an utter failure to attempt to assure a reasonable information and reporting system exists - will establish the lack of good faith that is a necessary condition to liability." "1 The test laid down by Chancellor Allen - a sustained or systematic failure of the board to exercise oversight - seems appropriate. The illustration - an "utter failure" - is certainly an example of a sustained or systematic failure, but it would be inappropriate if it were a test rather than an illustration.

Mc Call v. Scott, decided by the Sixth Circuit in 2001 under Delaware law, was a derivative action against former directors of another health-care provider, Columbia/HCA Healthcare Corporation. The claims arose out of widespread and systematic fraudulent schemes engaged in by Columbia, such

79698 A.2d at 970.

$80 \mathrm{Id}$.

81698 A.2d at 971 . 
as systematic overbilling. The complaint alleged that with the board's knowledge, Columbia's senior management devised these fraudulent schemes to improperly increase Columbia's revenue and profits, and to that end perpetuated a management philosophy that provided strong incentives for employees to engage in such schemes. The directors argued that the complaint should be dismissed because it alleged only a violation of the duty of care, and Columbia's certificate of incorporation included a shield provision, adopted pursuant to Delaware General Corporation Law $\$ 102(b)(7)$, which insulated directors from liability for violation of that duty. ${ }^{82}$ The court rejected this argument because the basis of the complaint was the director's conscious disregard of known risks. Such conduct violated the duty of good faith, and was therefore ineligible for protection under the shield. "[D]uty of care claims alleging only grossly negligent conduct are precluded by a $\$ 102(b)(7)$... provision, [but] it appears that duty of care claims based on reckless or intentional misconduct are not. ... [A] conscious disregard of known risks, ... if proven, cannot have been undertaken in good faith." ${ }^{83}$

Abbott Laboratories, decided by the Seventh Circuit in 2002 under Delaware law, was a derivative action against directors of Abbott, a pharmaceutical company. Plaintiffs alleged that over a seven-year period the directors had ignored both strong warnings from the Food and Drug Administration, and reports in the Wall Street Journal, that two of Abbott's production facilities were seriously and persistently deficient under the FDA's published standards. As a result of the deficiencies, and the lack of board action, the plants had to be closed down and Abbott suffered substantial losses. The court held that the complaint stated a claim that the directors had violated the duty of good faith:

Delaware law imposes three primary fiduciary duties on the directors of corporations; the duty of care, the duty of loyalty, and the duty of good faith ....

82 More accurately, the precise issue was whether the allegations in the complaint, if true, created a reasonable doubt that a majority of the board was disinterested, so that a derivative action could be brought without first making demand on the board. The governing rule was that "While the mere threat of personal liability is not sufficient, reasonable doubt as to the disinterestedness of a director is created when the particularized allegations in the complaint present 'a substantial likelihood' of liability on the part of the director." The directors argued that the allegations in the complaint did not create a substantial likelihood of liability, because the complaint essentially alleged that the board had violated the duty of care, and the directors were exculpated from dutyof-care liability under Columbia's shield provision.

83250 F.3d $997,1000-01$. 
... Given the extensive paper trail in Abbott concerning the violations and the inferred awareness of the problems, the facts support a reasonable assumption that there was a "sustained and systematic failure of the board to exercise oversight," in this case intentional in that the directors knew of the violations of law, took no steps in an effort to prevent or remedy the situation, and that failure to take any action for such an inordinate amount of time resulted in substantial corporate losses, establishing a lack of good faith. We find that six years of noncompliance, inspections, ... Warning Letters, and notice in the press, all of which then resulted in the largest civil fine ever imposed by the FDA and the destruction and suspension of products which accounted for approximately $\$ 250$ million in corporate assets, indicate that the directors' decision to not act was not made in good faith and was contrary to the best interests of the company....

The Sixth Circuit followed Delaware law in McCall in finding that the directors' fiduciary duties include not only the duty of care but also the duties of loyalty and good faith, stating that although "duty of care claims alleging only grossly negligent conduct are precluded by $\$ 102(\mathrm{~b})(7)$ waiver provision, it appears that duty of care claims based on reckless or intentional misconduct are not." ... The Mc Call court ... further stated, "Under Delaware law, the duty of good faith may be breached where a director consciously disregards his duties to the corporation, thereby causing its stockholders to suffer." ... Plaintiffs in Abbott accused the directors not only of gross negligence, but of intentional conduct in failing to address the federal violation problems, alleging "a conscious disregard of known risks, which conduct, if proven, cannot have been undertaken in good faith." ${ }^{84}$

Disney $I I I^{85}$ involved a motion to dismiss on the pleadings. Accordingly, the court assumed for purposes of the case that the facts alleged in the complaint were true. The facts, as assumed, were essentially as follows: Michael Eisner was Disney's chief executive officer. Disney needed a new president to be Eisner's second-in-command. Eisner chose Michael Ovitz, who had been Eisner's close friend for over twenty-five years. In September 1995, Disney prepared a draft five-year employment agreement for Ovitz. At a meeting of the board's compensation committee on September 26, the committee members were provided with a rough summary of the agreement, but not the draft agreement itself, and even the summary was incomplete. The summary stated that Ovitz was to receive options to purchase five million shares of stock, but 
did not state the exercise price. Furthermore, no analytical document that showed the potential payout to Ovitz, or the possible cost of his severance package, was either created or presented to the committee. The committee neither requested nor received any information concerning how the draft agreement compared with agreements in the entertainment industry with similarly situated executives. The committee nevertheless approved the general terms and conditions of the employment agreement. Disney's board met immediately after the compensation committee meeting. Again, no documents were produced for the board to review before the meeting, and the board did not consider the various payout scenarios if a termination occurred.

Final negotiation of the employment agreement was left to Eisner, Ovitz's close friend. Neither the board nor the compensation committee reviewed or approved the final agreement. The final agreement differed significantly from the draft summarized to the compensation committee. One major difference concerned the circumstances surrounding Ovitz's severance benefits. The draft provided that in the case of a "non-fault" termination, Ovitz would receive very substantial benefits, but that a non-fault termination would occur only if Disney wrongfully terminated Ovitz, or Ovitz died or became disabled. In contrast, the final agreement stated that Ovitz would receive nonfault termination benefits if he was terminated by Disney and had not acted with gross negligence or malfeasance. Therefore, under the final agreement Ovitz would receive "non-fault" termination benefits even if he was terminated by Disney because he acted negligently, as long as his behavior did not reach the level of gross negligence or malfeasance.

Ovitz's tenure as Disney's president was extremely unsuccessful. Although Ovitz admittedly did not know his job, he studiously avoided attempts to be educated. Instead of working to learn his duties as Disney's president, Ovitz began seeking alternative employment. Under his contract, Ovitz could properly terminate his employment only if one of four designated events occurred. None of these events ever occurred. However, Eisner re-wrote Ovitz's contract so that in the event of Ovitz's voluntary departure for any reason, Disney would pay him the benefits provided for a non-fault termination. In the event, Ovitz received termination benefits of $\$ 140$ million for doing a terrible job for one year.

If the alleged facts were true, Disney's directors would have violated their duty of care, but the directors would have been insulated from liability for violation of that duty by Disney's shield provision. However violations of the duty of good faith are not protected under the Delaware shield provision, and on the basis of "the foundational directoral obligation to act honestly and 
in good faith to advance corporate interests "s6 the court held that if the alleged facts were true, the directors' conduct was also not in good faith.

These facts, if true, do more than portray directors who, in a negligent or grossly negligent manner, merely failed to inform themselves or to deliberate adequately about an issue of material importance to their corporation. Instead, the facts alleged in the ... complaint suggest that the defendant directors conscionsly and intentionally disregarded their responsibilities, adopting a "we don't care about the risks" attitude concerning a material corporate decision. Knowing or deliberate indifference by a director to his or her duty to act faithfully and with appropriate care is conduct ... that may not have been taken honestly and in good faith to advance the best interests of the company. Put differently, all of the alleged facts, if true, imply that the defendant directors knew that they were making material decisions without adequate information and without adequate deliberation, and that they simply did not care if the decisions caused the corporation and its stockholders to suffer injury or loss. Viewed in this light, plaintiffs' ... complaint sufficiently alleges a breach of the directors' obligation to act honestly and in good faith in the corporation's best interests ... ${ }^{87}$

After the denial of the motion to dismiss on the pleadings, the case went to trial. The evidence at trial diverged from the allegations in the complaint, and on the basis of that evidence, in Disney IV, Chancellor Chandler held for the defendants. In the course of his opinion, the Chancellor elaborated on the duty of good faith as follows:

Bad faith has been defined as authorizing a transaction "for some purpose other than a genuine attempt to advance corporate welfare or [when the transaction] is known to constitute a violation of applicable positive law." In other words, an action taken with the intent to harm the corporation is a disloyal act in bad faith. A similar definition was used seven years earlier, when Chancellor Allen wrote that bad faith (or lack of good faith) is when a director acts in a manner "unrelated to a pursuit of the corporation's best interests." It makes no difference the reason why the director intentionally fails to pursue the best interests of the corporation.

Bad faith can be the result of "any emotion [that] may cause a director to [intentionally] place his own interests, preferences or appetites before the welfare of the corporation," including greed, "hatred, lust, envy, revenge, ... shame or pride." Sloth could certainly be an appropriate addition to 
that incomplete list if it constitutes a systematic or sustained shirking of duty....

... [T] The defendants' motion to dismiss this action was denied because I concluded that the complaint ... alleged that Disney's directors "consciously and intentionally disregarded their responsibilities, adopting a 'we don't care about the risks' attitude concerning a material corporate decision."

Upon long and careful consideration, I am of the opinion that the concept of intentional dereliction of duty, a conscious disregard for one's responsibilities, is an appropriate (although not the only) standard for determining whether fiduciaries have acted in good faith....

... The good faith required of a corporate fiduciary includes not simply the duties of care and loyalty, in the narrow sense that I have discussed them above, but all actions required by a true faithfulness and devotion to the interests of the corporation and its shareholders. A failure to act in good faith may be shown, for instance, where the fiduciary intentionally acts with a purpose other than that of advancing the best interests of the corporation, where the fiduciary acts with the intent to violate applicable positive law, or where the fiduciary intentionally fails to act in the face of a known duty to act, demonstrating a conscious disregard for his duties. There may be other examples of bad faith yet to be proven or alleged, but these three are the most salient. ${ }^{88}$

The cases use various formulations as tests for determining when the magnitude of disregard of responsibilities rises to so high a level that a manager has violated not only the duty of care, but the duty of good faith. These tests include "a sustained or systematic failure of the board to exercise oversight," 89 "reckless or intentional misconduct," "a conscious disregard of known risks," "consciously and intentionally disregard[ing] ... responsibilities," 92 "adopting a 'we don't care' about the risks' attitude concerning a material corporate decision," ${ }^{3}$ "intentional dereliction of duty," "conscious disregard for one's responsibilities," "95 "sloth ... if it constitutes a systematic of

882005 WL 2056651 at $* 35-36$.

89 Caremark at 971.

$90 \mathrm{McCall}$ at 1000-01; Abbott at 811.

$91 \mathrm{McC}$ Call at 1000-01; Abbott at 811.

92 Disney $I I I$ at 289; Disney IV at *35; Emerging at *43.

93 Disney III at 289; Emerging at "43.

94 Disney $I V$ at *135-36.

95 Disney $I V$ at *135-36. 
sustained shirking of duties," 96 and "[K]nowing or deliberate indifference ... [to one's] duty to act faithfully and with appropriate care." 97

These tests are not conflicting. Rather, they are various ways to indicate the magnitude and type of disregard required to establish a breach of the duty of good faith on the basis of disregard of one's responsibilities. Chancellor Chandler said as much in Disney IV: "the concept of intentional dereliction of duty, a conscious disregard for one's responsibilities, is an appropriate (although not the only) standard for determining when fiduciaries have acted in good faith."

The terms "intentional" and "conscious," as used in that and some other tests, need interpretation. The formulations that employ these terms would make little or no sense unless they mean either that the manager was conscious that he was disregarding his duties or that a reasonable person in the manager's position would have known that he was disregarding his duties not that the actual manager was subjectively conscious that he was disregarding his duties. Surely it would be no defense, in such a case, that the manager, on being asked, "Were you consciously disregarding your duties?," truthfully replied, "No" or "I didn't think about it one way or the other."

Once that is understood, it is not necessary to choose a single formulation of when disregard of responsibilities rises to a level of magnitude that constitutes a violation of the duty of good faith, because there is more than one way for disregard to rise to that level. For simplicity, I will use the term substantial disregard of responsibilities to embody that level, on the understanding that this term (i) is intended to capture any unjustifiable or inexplicable disregard of responsibilities that is either persistent or concerns a very important event, and (ii) is intended to embrace, rather than supplant, the various formulations that have been used in the cases.

\section{Conclusion}

An important development in American corporate law is the recent explicit recognition, in a series of Delaware cases, that managers have a fiduciary duty of good faith. That duty was not created by those cases. On the contrary, the duty has long been explicit under the statutes - for example, in statutory provisions that require directors to act in good faith, and in provisions concern-

96 Disney $I V$ at ${ }^{*} 135-36$.

97 Disney $I I I$ at 289.

98 Disney $I V$ at 136. (Emphasis added; emphasis by the court deleted.) 
ing indemnification. The duty of good faith has also long existed implicitly in the case law - for example, in the formulation of the business-judgment rule, and in fiduciary obligations that can only be explained by that duty, such as the rule that a manager acts improperly if he knowingly causes the corporation to take an illegal action. Nevertheless, the explicit recognition of the duty of good faith in recent Delaware cases shines a spotlight on that duty, and therefore makes it especially important to develop the contours of the duty and to examine the duty from a normative perspective. It is these two issues with which this article has been primarily concerned.

Briefly, the duty of good faith in American corporate law is comprised of a general baseline conception and specific obligations that instantiate that conception. The baseline conception consists of four elements: subjective honesty, or sincerity; nonviolation of generally accepted standards of decency applicable to the conduct of business; nonviolation of generally accepted basic corporate norms; and fidelity to office. Among the specific obligations that instantiate the baseline conception are the obligation not to knowingly cause the corporation to disobey the law; the obligation of candor even in non-self-interested contexts; the obligation not to act on the basis of impermissible although non pecuniary motives; and the obligation not to substantially disregard one's responsibilities.

Turning to the normative issue, there are several basic reasons why the duty of good faith is desirable. To begin with, the duties of care and loyalty do not cover all types of improper conduct by managers, because certain kinds of improper managerial conduct fall outside the spheres of those duties. Most of these types of conduct fall within the duty of good faith. Furthermore, various rules limit a manager's accountability under the duties of care and loyalty, and these limiting rules should be and are inapplicable to conduct that violates the duty of good faith. Moreover, the duties of care and loyalty characteristically (although not invariably) function as platforms for liability rules, while the duty of good faith characteristically (although not invariably) functions as a condition to the application of rules that do not in themselves impose liability. This difference in characteristic function makes it desirable to treat good faith separately from care and loyalty. Finally, the duty of good faith provides a principled basis for the courts to develop new specific fiduciary obligations that come to be seen as appropriate in response to changes in social and business norms, and in the general understanding of efficiency and other policy considerations that are applicable to corporate law, but cannot be accommodated within the duties of care or loyalty.

The last of these reasons suggests that the duty of good faith has a Janus-like quality, looking both backward and forward. Looking backward, the duty of 
good faith rationalizes and explains a variety of specific obligations that are already established although they do not fit comfortably or at all within the duties of care and loyalty, such as the obligation not to knowingly cause the corporation to disobey the law, and the obligation of candor even in nonselfinterested contexts. Looking forward, the duty of good faith may give rise to further specific obligations if and when business norms, shareholder expectations, and efficiency and other policy considerations evolve in new directions. 